\title{
Differences in metal content in liver of Heteromyids from deposits with and without previous mining operations
}

\author{
Lía Méndez-Rodriguez ${ }^{1 *}$ and Sergio Ticul Álvarez-Castañeda' \\ ${ }^{1}$ Centro de Investigaciones Biológicas del Noroeste, S. C. Av. Instituto Politecnico Nacional 194, CP. 23096, La Paz. Baja California \\ Sur, México. Email: Lmendez04@cibnor.mx (LM-R), sticul@cibnor.mx (STA-C). \\ * Corresponding author
}

Some rodents of the family Heteromyidae can survive without drinking water, as they obtain it from food. All these species have in common that they eat seeds and fruits. The content of trace metals in food varies depending on the local geology and anthropogenic activities. Baja California Sur has mineral deposits that have been exploited; thus, the metals released may be incorporated into seeds and fruits that are consumed by Heteromyidae. Therefore, metal content in the liver is expected to reflect the presence of mining in soil where these rodents thrive. Individuals from different species of Heteromyidae were collected at sites with mineral deposits; these were divided into two groups: rodents captured in sites with a history of mining operations (Santa Rosalia, San Juan de la Costa, and El Triunfo), and rodents captured in areas with no mining activities (El Vizcaíno, Punta Abreojos, Magdalena Island, and Santiago). The liver of these rodents was excised and its manganese, copper, cadmium, lead, zinc, nickel, and iron contents were determined using atomic absorption spectrophotometry. Manganese was the element that showed the highest significant differences between species, followed by zinc and copper. Iron and cadmium showed the lowest differences. Nickel and lead showed no differences. Chaetodipus arenarius showed significant differences between sites in copper and lead content; C. spinatus did not show significant differences for manganese, copper, nickel, and iron, but it did for cadmium and lead content. Differential accumulation of metals occurs across species. These results indicate that the same species could be used for comparative purposes in pollution monitoring. The comparison of different heteromid species, despite their sharing similar feeding habits and belonging to the same family, can lead to misinterpretation due to the variability of the results. This is probably due to the requirements and tolerances regarding essential elements, such as manganese and zinc, to or tolerance to non-essential elements such as cadmium and lead, which may vary across species.

Algunas especies de roedores de la familia Heteromyidae pueden sobrevivir sin tomar agua debido a que la obtienen del alimento que consumen. Todas las especies de esta familia, tienen en común que se alimentan de semillas y frutos. El contenido de metales en el alimento puede variar dependiendo de la geología y las actividades antropogénicas que se desarrollen en el yacimiento donde habiten. En Baja California Sur se encuentran yacimientos de minerales que han sido explotados a través de la minería. Los metales liberados se pueden incorporar en las semillas y frutos de los que se alimentan los Heteromyidae. Por lo tanto, es de esperar que el contenido de metales en el hígado de los roedores refleje la presencia de minería en el habitat en que viven. Ejemplares de diferentes especies de Heteromyidae fueron colectados en sitios con yacimientos de minerales los cuales se dividieron en dos grupos. Con antecedentes de actividad minera (Santa Rosalía, San Juan de la Costa y El Triunfo) y sin actividad minera (El Vizcaíno, Punta Abreojos, Isla Magdalena y Santiago). Los hígados de los roedores fueron extraídos y analizados en su contenido de manganeso, cobre, cadmio, plomo, zinc, níquel y hierro por espectrofotometría de absorción atómica. El manganeso fue el elemento que presentó mayor cantidad de diferencias significativas entre especies, seguido por el zinc y el cobre y en menor medida de el hierro y el cadmio. El níquel y el plomo no presentaron diferencias. Chaetodipus arenarius presentó diferencias significativas entre yacimientos en su contenido de cobre y plomo, mientras que $C$. spinatus no presentó diferencias significativas de manganeso, cobre, níquel y hierro, pero si en cadmio y plomo. Se observa acumulación diferencial de metales entre especies. Los resultados indican que una misma especie debe ser utilizada para fines comparativos en monitoreos de contaminación. Comparar distintas especies, aunque todos sean heterómidos y tengan alimentaciones similares, puede causar interpretaciones erróneas. Esto se debe a que los requerimientos y tolerancias de elementos esenciales para la vida, como son manganeso y zinc, o la tolerancia hacia elementos no esenciales como cadmio y plomo, pueden variar entre especies.

Keywords: bioaccumulation; bioindicators; chemical pollution; rodents; arid soils.

C 2019 Asociación Mexicana de Mastozoología, www.mastozoologiamexicana.org

\section{Introduction}

The Baja California peninsula, Mexico, includes regions with mineral deposits; El Vizcaíno has copper and nickel streaks; Santa Rosalia has copper, iron, zinc, and manganese deposits; El Triunfo-San Antonio, lead, zinc, and copper; and Sierra de San Francisco, copper (Servicio Geológico Mexicano 2017). In the municipalities of Loreto (San Hilario-Santa Rita), La Paz (Tembabiche, San Juan de la Costa), and Comondú (San Domingo and La Bocana), there are phosphorite deposits, composed of $70 \%$ to $80 \%$ spheroidal phosphate grains, used mainly as agricultural fertilizer (Consejo de
Recursos Mineros 1999; Servicio Geológico Mexicano 2017). These deposits also contain trace elements (these elements are named as trace because they are commonly found in environmental concentrations below $0.1 \%$ (Pais and Jones 1997) and lower than $0.01 \%$ of body weight in animal and plant tissues (Adriano 2001), including cadmium, manganese, zinc, and lead (Alshahri and Alqahtani 2015).

These deposits that have been exploited through mining are located in three mining districts. The most important is Santa Rosalia, mainly dedicated to copper extraction; San Juan de la Costa, to phosphorite; and, to a lesser extent, 
El Triunfo-San Antonio, to gold and silver (Consejo de Recursos Mineros 1999; Servicio Geológico Mexicano 2017).

Santa Rosalia is located in northern Baja California Sur, where mining operations related to copper extractions were conducted from the mid-19th to the late 20th centuries and resumed in the early 21st century (Consejo de Recursos Mineros 1999). Beach sand in this area contains copper (up to $30,380 \mu \mathrm{g} \cdot \mathrm{g}^{-1}$ ), zinc (up to $26,970 \mu \mathrm{g} \cdot \mathrm{g}^{-1}$ ), and lead (up to $2,100 \mu \mathrm{g} \cdot \mathrm{g}^{-1}$ ) in levels above those recorded in sediments polluted from industrial operations in Russia (Shumilin et al. 2000). Phosphorite was extracted at San Juan de la Costa from 1975 to 2003, when the mine closed because its facilities were damaged by a hurricane, and resumed operations from 2007 to date (Panorama Minero de Baja California Sur 2008). Mining activities, primarily gold extraction, were also conducted in San Antonio and El Triunfo, in the south of the Baja California peninsula, since the mid-18th century until the early twentieth century; no extraction activities are currently performed (Consejo de Recursos Mineros 1999; Servicio Geológico Mexicano 2017). During more than 150 years of gold mining in the San Antonio-El Triunfo area, several deposits of mineral waste were produced with high contents of trace metals such as cadmium $\left(203 \mu \mathrm{g} \cdot \mathrm{g}^{-1}\right)$, copper $\left(882 \mu \mathrm{g} \cdot \mathrm{g}^{-1}\right)$, and lead $\left(29,364 \mu \mathrm{g} \cdot \mathrm{g}^{-1}\right.$; Méndez-Rodríguez and Álvarez-Castañeda 2016), relative to the values considered as typical of the earth's crust (cadmium: $0.2 \mu \mathrm{g} \cdot \mathrm{g}^{-1}$; copper: $55 \mu \mathrm{g} \cdot \mathrm{g}^{-1}$, and lead: $12.5 \mu \mathrm{g} \cdot \mathrm{g}^{-1}$, Taylor 1964).

Baja California Sur has mineral deposits not yet exploited, as those in Santiago (copper deposits), Magdalena Island, Abreojos (offshore phosphorite deposits) and the Vizcaíno Desert, (scattered copper and nickel streaks; Servicio Geológico Mexicano 2017). Areas with mineral deposits can contain amounts of various metals above the average concentrations in the earth's crust, either in soil or in air (Taylor 1964; Hunter et al. 1987). The presence of a trace element such as lead or cadmium in a mineral deposit does not necessarily mean that it is readily available for accumulation by organisms living in the area, that is to say, that it is bioavailable. The bioavailable fraction of a chemical is largely determined by its solubility, which in turn depends on its chemical properties (Allen 2002). The chemical properties of an element may be affected by environmental factors such as water $\mathrm{pH}$ and salinity (Kim et al. 2015).

Except for a study conducted in the southern Baja California peninsula (Méndez-Rodríguez and Álvarez-Castañeda 2016), the content and variability of trace elements in mammals living in mining areas is still unknown. Heteromid species have been found in all areas with mineral deposits; these have been used as bioindicators of pollution by trace elements (cadmium, lead, manganese, zinc, and nickel; Méndez-Rodríguez and Álvarez-Castañeda 2016).

Heteromids bioaccumulate trace elements taken up from food (Méndez-Rodríguez and Álvarez-Castañeda 2016). Bioaccumulation refers to the elements that are accumulated in organisms from solid intake (food, air inspired, sediments, and grooming); it differs from bioconcentration, which deals with elements taken up by drinking water (Kim et al. 2015). Bioaccumulation is not influenced by fluctuations in the composition of trough water, which in turn may depend on several factors such as the time of the year (rainy or dry season) and the occurrence of natural or anthropogenic pollution events.

The objective of this study was to determine potential differences in trace elements content across the species of heteromid rodents living in a site with mineral deposits. It also seeks to establish whether the trace elements content within the same heteromid species may vary significantly between sites with mineral deposits, with and without records of mining operations.

\section{Materials and Methods}

The specimens studied were collected in May 1998 from areas with mineral deposits with and without mining operations. To this end, Sherman traps were placed along transects, with a total of 600 nights/traps per locality. The deposits sampled were divided into two groups: A) with mining activity: Santa Rosalia, San Juan de la Costa and El Triunfo, and B) with no mining operations: Vizcaíno, Abreojos, Magdalena Island and Santiago (Consejo de Recursos Mineros 1999; Servicio Geológico Mexicano 2017; Figure 1). The four species collected are associated with different types of substrate: Chaetodipus arenarius, areas with sandy substrate; C. spinatus, rocky outcrops; C. rudinoris, loamy or clayey soils; and Dipodomys simulans, clayey or sandy soils of more than 15 centimeters deep (Patton and ÁlvarezCastañeda 1999; Gutierrez-Ramos and Álvarez-Castañeda 1999). Since each deposit has limited types of substrates, our expectation was to find not the four species in each locality, but an average of two species per locality. For statistical analysis, we only considered the species for which eight individuals were captured. All specimens analyzed were adults (age 4, sensu Hoffmeister 1951).

Analysis of trace elements. The analyses of trace elements were carried out in the liver of specimens collected. This tissue has been useful to reflect environmental differences in trace elements content between substrates associated with small mammals (Talmage and Walton 1991). The specimens were transported to the laboratory in coolers. The liver of the specimens of the four species of was excised and drystored individually under freezing until analysis (MéndezRodríguez and Álvarez-Castañeda 2016). In the laboratory, each liver was dried in an oven at $70{ }^{\circ} \mathrm{C}$ and subsequently weighed. The concentration of trace elements was recorded in milligrams (dry weight). Each sample was digested separately using a solution of $70 \%$ nitric acid $\left(\mathrm{HNO}_{3}\right)$ and $30 \%$ hydrogen peroxide $\left(\mathrm{H}_{2} \mathrm{O}_{2}\right.$; Analytical grade; Mallinckrodt J. T. Baker, USA) in a microwave oven (Mars 5X, CEM; Matthews, USA; Méndez-Rodríguez and Álvarez-Castañeda 2016). After digestion, $1 \mathrm{ml}$ of hydrochloric acid $(\mathrm{HCl})$ was added to each sample and then brought to $50 \mathrm{~mL}$ with dis- 
tilled water. Manganese (Mn), copper (Cu), cadmium (Cd), lead $(\mathrm{Pb})$, zinc $(\mathrm{Zn})$, nickel $(\mathrm{Ni})$, and iron $(\mathrm{Fe})$ concentrations were determined using an atomic absorption spectrophotometer (Xploraa, GBC Scientific Equipment) with airacetylene flame (Van Loon 1985). Values were calibrated and validated using the certified reference standard TORT-2 (National Research Council Canada, Ottawa). The analytical values were within the range of the certified values. Metals recovery was higher than $95 \%$. The concentrations of trace elements reported in other studies based on fresh weight were converted to dry weight by multiplying by 3.5 (Talmage and Walton 1991). The limits of detection of the instrument were as follows: $\mathrm{Mn}, 0.020 \mu \mathrm{g} \cdot \mathrm{g}^{-1} ; \mathrm{Cu}, 0.017 \mu \mathrm{g} \cdot \mathrm{g}^{-}$ ${ }^{1} ; \mathrm{Cd}, 0.017 \mu \mathrm{g} \cdot \mathrm{g}^{-1} ; \mathrm{Pb}, 0.074 \mu \mathrm{g} \cdot \mathrm{g}^{-1} ; \mathrm{Zn}, 0.070 \mu \mathrm{g} \cdot \mathrm{g}^{-1} ; \mathrm{Ni}, 0.030$ $\mu \mathrm{g} \cdot \mathrm{g}^{-1} ; \mathrm{Fe}, 0.65 \mu \mathrm{g} \cdot \mathrm{g}^{-1}$.

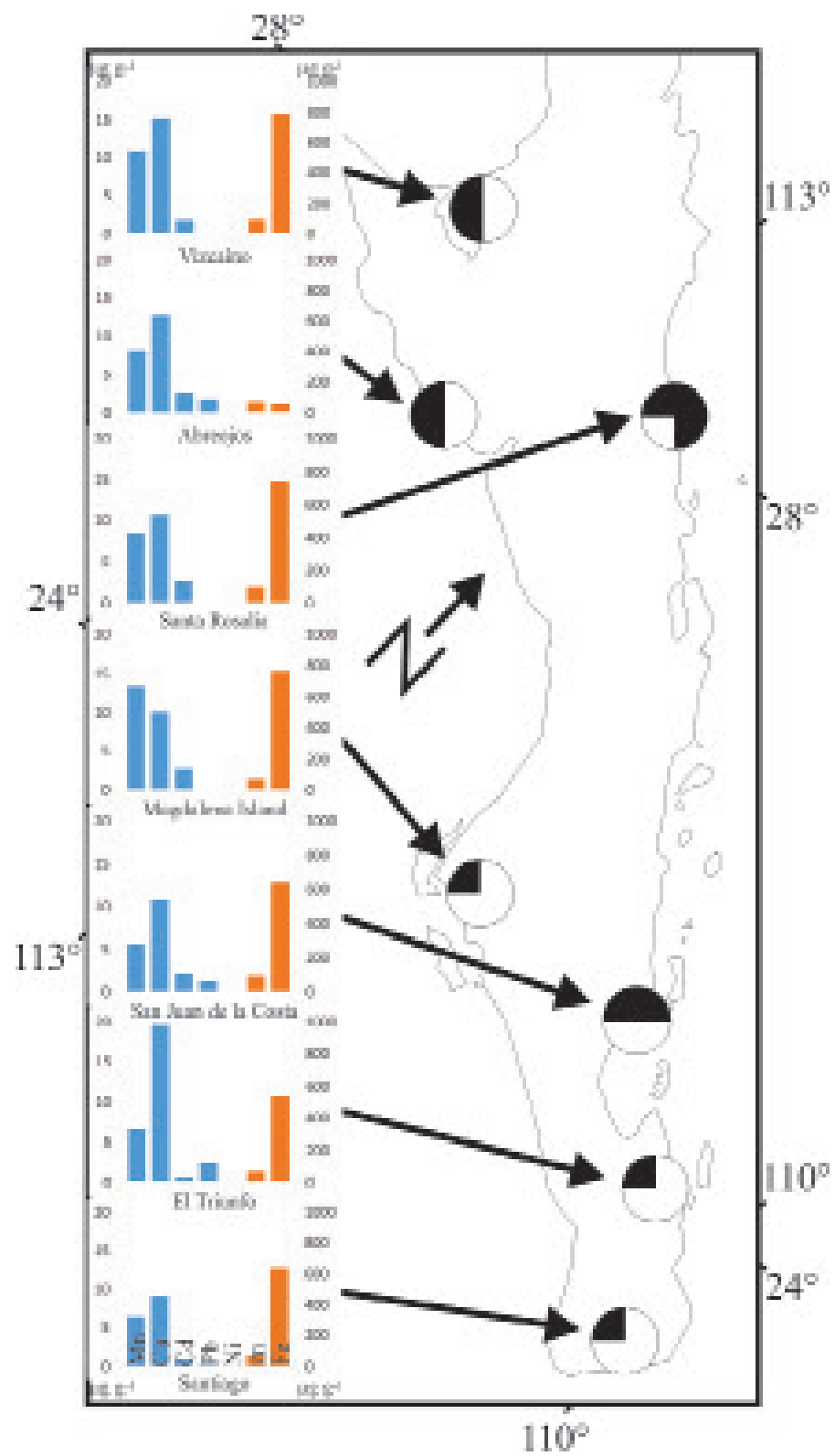

Figure 1. Sites where specimens of Chaetodipus arenarius, C. spinatus, C. rudinoris, and Dipodomys simulans were collected in Baja California Sur, Mexico. Columns in blue are related to the $\mathrm{Y} 1$ axis; columns in orange, with $\mathrm{Y} 2$. The presence of the different species in each site is marked. The top left quarter represents the presence of $C$. spinatus, top right $=C$. rudinoris; bottom left $=C$. arenarius; and lower right $=D$. simulans.
Statistical analysis. The normality and homoscedasticity of the concentration data of each trace element were analyzed using the Kolmogorov-Smirnov and Levene tests, respectively. The concentration data of the seven elements were log-transformed and compared by a one-way ANOVA, to test for significant differences in trace element concentrations between different species in a locality or between individuals of the same species from different localities. A Tukey's post-hoc analysis was conducted (Zar 2010). The analyses were carried out using the software STATISTICA (StatSoft, Inc 10). The data are reported as the mean \pm standard error. The results with a significance level of $P<0.05$ were considered statistically significant. The presence of synergies (an element favors the presence of another element in a tissue) or antagonisms (higher concentrations of an element associated with lower levels of another) between elements was explored using Pearson's correlations (Schoendorfer and Davies 2012; Mikolic et al. 2016).

\section{Results}

Different heteromid species coexisting in a given deposit. A total of four heteromid species were found across the whole study area. In a single deposit, up to two species were found with more than eight individuals, depending on the type of substrate (Table 1). This prevented the comparison of the four species in a single deposit, but pairwise comparisons were performed in different deposits. In sites where individuals belonging to more than one species were found, manganese was the element that showed the greatest number of significant differences between species (Table 1). In El Vizcaino, C. spinatus showed significantly higher manganese $(P=0.005)$ and zinc $(P=0.002)$ concentrations, and lower copper levels $(P=0.0001)$, versus $C$. arenarius. There were no significant differences in cadmium, lead, nickel, or iron. In Santa Rosalia, C. spinatus showed significantly higher manganese $(P=0.0002)$ and zinc $(P$ $=0.0058)$ concentrations, but a lower cadmium level $(P=$ $0.0273)$, relative to Dipodomys simulans; no significant differences were observed for copper, lead, nickel, and iron. In San Juan de la Costa, $C$. spinatus showed significantly higher manganese $(P=0.0004)$ and copper $(P=0.0114)$ concentrations, but lower cadmium $(P=0.0114)$ and iron $(P=0.0024)$ levels, versus $C$. rudinoris, with significant differences in lead, zinc, and nickel. In most deposits, C. spinatus showed significantly higher manganese and lower cadmium levels, relative to the other heteromid species coexisting with it.

Same species living in different deposits. The species that prevailed in the deposits studied was C. spinatus (Table 1). The metals content in specimens of this species in the seven sites showed no significant differences in manganese, copper, nickel, and iron levels. Cadmium levels in specimens from Magdalena Island were significantly higher versus those in specimens from Santiago $(P=0.0104)$, San Juan de la Costa $(P=0.0356)$ and El Triunfo $(P=0.0229)$. San Juan de la Costa showed significantly higher lead concentrations than Magdalena Island $(P=0.0126)$, Santa Rosalia $(P=$ 


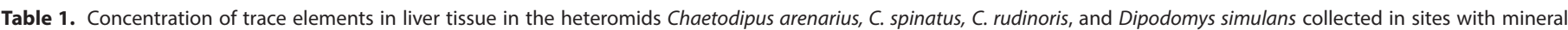
deposits in Baja California Sur, Mexico.

\begin{tabular}{|c|c|c|c|c|c|c|c|c|c|}
\hline & Especie & $n$ & Manganese & Copper & Cadmium & Lead & Zinc & Níckel & Iron \\
\hline \multicolumn{10}{|c|}{ Without mining activity } \\
\hline \multirow[t]{2}{*}{ El Vizcaino } & C. arenarius & 10 & $8.37 \pm 0.38$ & $18.18 \pm 0.98$ & $1.88 \pm 0.17$ & $0.41 \pm 0.37$ & $86.37 \pm 5.18$ & $<0.02$ & $821 \pm 43$ \\
\hline & C. spinatus & 9 & $13.86 \pm 1.78$ & $12.32 \pm 0.81$ & $1.94 \pm 0.26$ & $<0.17$ & $120.99 \pm 8.22$ & $0.16 \pm 0.16$ & $758 \pm 76$ \\
\hline \multirow[t]{2}{*}{ Abreojos } & C. arenarius & 15 & $7.93 \pm 0.43$ & $12.62 \pm 0.85$ & $2.85 \pm 0.61$ & $1.73 \pm 0.50$ & $77.89 \pm 4.18$ & $<0.02$ & $852 \pm 76$ \\
\hline & C. spinatus & 1 & 12.38 & 15.51 & 1.29 & 3.92 & 89.45 & $<0.02$ & 796 \\
\hline Isla Magdalena & C. spinatus & 10 & $13.50 \pm 5.01$ & $10.19 \pm 3.35$ & $3.00 \pm 0.61$ & $<0.17$ & $79.01 \pm 18.05$ & $<0.02$ & $774 \pm 147$ \\
\hline \multicolumn{10}{|c|}{ With mining activity } \\
\hline \multirow[t]{3}{*}{ Santa Rosalia } & C. rudinoris & 1 & 11.31 & 7.39 & 5.15 & $<0.17$ & 97.27 & $<0.02$ & 549 \\
\hline & C. spinatus & 13 & $10.84 \pm 0.87$ & $11.79 \pm 1.95$ & $2.15 \pm 0.34$ & $0.09 \pm 0.08$ & $118.55 \pm 8.87$ & $0.12 \pm 0.11$ & $807 \pm 62$ \\
\hline & D. simulans & 10 & $5.66 \pm 0.32$ & $9.75 \pm 0.61$ & $3.61 \pm 0.40$ & $<0.17$ & $78.62 \pm 4.99$ & $<0.02$ & $699 \pm 40$ \\
\hline \multirow[t]{2}{*}{ S. J. Costa } & C. rudinoris & 10 & $3.60 \pm 0.73$ & $9.96 \pm 0.62$ & $3.30 \pm 0.57$ & $0.58 \pm 0.26$ & $103.01 \pm 8.54$ & $<0.02$ & $749 \pm 64$ \\
\hline & C. spinatus & 8 & $8.25 \pm 0.64$ & $12.95 \pm 0.76$ & $1.35 \pm 0.25$ & $2.24 \pm 1.05$ & $107.44 \pm 4.20$ & $0.50 \pm 0.48$ & $449 \pm 46$ \\
\hline El Triunfo & C. spinatus & 11 & $7.77 \pm 0.56$ & $13.37 \pm 1.23$ & $1.11 \pm 0.11$ & $1.92 \pm 0.69$ & $75.32 \pm 6.61$ & $<0.02$ & $773 \pm 88$ \\
\hline Santiago & C. spinatus & 10 & $6.54 \pm 1.26$ & $9.22 \pm 1.84$ & $1.13 \pm 0.33$ & $0.43 \pm 0.30$ & $72.75 \pm 13.26$ & $0.22 \pm 0.22$ & $642 \pm 127$ \\
\hline
\end{tabular}

0.0113), and El Vizcaíno ( $P=0.0000)$, but these were not significantly different versus Santiago. At El Vizcaíno, C. arenarius showed the highest copper levels $(P=0.0004)$ and the lowest lead levels ( $P=0.0450$ ) relative to Abreojos (Table 1 ).

Correlations between metals by species and site. In San Juan de la Costa, C. rudinoris yielded a direct correlation between manganese and copper contents $(r=0.89)$, and an inverse correlation between manganese and cadmium $(r=-0.84)$. In C. spinatus, nickel was directly correlated to lead $(r=0.82)$, and inversely correlated to cadmium ( $r=$ -0.77). In C. spinatus and C. rudinoris manganese $(r=0.76)$ and copper $(r=0.62)$ show a direct correlation; the opposite, i.e., an inverse correlation between these two species was observed for iron $(r=-0.67)$ and cadmium $(r=-0.58)$. These findings suggest that both species living in the same deposit behave differently in terms of bioaccumulation. Although an increase in manganese and copper levels co-occurs in both species in San Juan de la Costa, iron and cadmium increases in C. rudinoris while both elements decreases in C. spinatus or vicebersa. Zinc and nickel show non-significant differences between these two species coexisting in the same locality.

In Santa Rosalia, no significant correlation was found between metals in D. simulans or C. spinatus. However, a direct correlation in manganese $(r=0.52)$ and zinc $(0.53)$ was evident between these two species, but an inverse correlation in cadmium ( $r=-0.59)$ was observed. In other words, in both species, manganese and zinc contents either increased or decreased in parallel in both species; however, when cadmium increases in D. simulans, it decreases in C. spinatus.

In El Vizcaino, $C$. arenarius showed a direct correlation between manganese and copper $(r=0.69)$ and between manganese and zinc ( $r=0.68)$; in contrast, $C$. spinatus showed no significant correlations between the content of these metals. Both species showed a direct correlation in manganese $(r=0.61)$ and zinc $(r=0.66)$ content, but and inverse correlation in copper $(r=-0.74)$ content. In Abreojos, $C$. arenarius showed a direct correlation between copper and cadmium $(r=0.52)$, copper and zinc $(r=0.84)$, and cadmium and zinc $(r=0.63)$.

In El Triunfo, Santiago and Isla Magdalena, only C. spinatus individuals were found. El Triunfo specimens showed no significant correlation between metals content. In Santiago, manganese was significantly correlated $(P<0.05)$ to copper $(r=0.84)$, zinc $(r=0.79)$ and iron $(r=0.81)$. In addition, a direct correlation was observed between copper and zinc $(r=0.93)$, and between copper and iron ( $r=0.97)$. Lead was directly correlated with nickel $(r=0.84)$, and iron with zinc $(r=0.94)$. The specimens collected in Magdalena Island showed a significant direct correlation between copper and zinc $(r=0.80)$.

\section{Discussion}

Mineral deposits have high metal concentrations relative to those considered typical of the earth's crust (Taylor 1964); this does not imply, however, that these metals are bioavailable. The concentrations found in the liver of rodents collected in the different deposits show mean manganese, copper, zinc, and nickel levels that are below the values considered characteristic of non-contaminated sites: manganese (up to $1320 \mu \mathrm{g} \cdot \mathrm{g}^{-1}$ ); copper (up to $23 \mu \mathrm{g} \cdot \mathrm{g}^{-1}$ ); zinc (up to $120 \mu \mathrm{g} \cdot \mathrm{g}^{-1}$ ); nickel (up to $4.80 \mu \mathrm{g} \cdot \mathrm{g}^{-1}$; Talmage and Walton 1991; Lewis et al. 2001; Torres and Johnson 2001; Milton et al. 2003). These four elements are essential for life; hence, their levels in the body are regulated by physiological mechanisms that produce a balance between assimilation, metabolism, and excretion (Fritsch et al. 2010).

Cadmium concentrations in the liver of specimens collected in the seven sites studied, regardless of the presence of mining operations, are within the range considered normal for this element (Marques et al. 2007; Petkovšek et al. 2014), suggesting that the rodents studied are not bioaccu- 
mulating this metal. In deposits with presence of foundry facilities, the cadmium levels recorded are almost one order of magnitude higher than those found in the present study $\left(\approx 50 \mu \mathrm{g} \cdot \mathrm{g}^{-1}\right.$; Dimitrov et al. 2016). In Slovenia, in deposits affected by lead foundries, which are also sources of cadmium pollution to the environment, the granivorous rodent Apodemus flavicollis shows concentrations higher than those recorded in the present study, ranging from about $19.0 \pm 20.0 \mu \mathrm{g} \cdot \mathrm{g}^{-1}$ up to $15.5 \pm 19.4 \mu \mathrm{g} \cdot \mathrm{g}^{-1}$ (Petkovšek et al. 2014; Dimitrov et al. 2016), which are twice those recorded in the present study (Table 1).

It is considered that the levels of trace elements in soil will be reflected in the liver of rodents thriving in these sites, since metals in the substrate are likely taken up by local plants (Méndez-Rodríguez and Álvarez-Castañeda 2016) and, in this way, can be incorporated into the food chain. In plants, however, trace elements may be present as a nonbioavailable moiety, for example, if they occur as phytates (Schoendorfer and Davis 2012). Therefore, cadmium levels in sediments or the diet may not be directly related to its concentrations in body tissues. Another factor to consider is that a set of antagonistic or synergistic chemicals are also taken up with food. For example, seeds consumed by rodents in El Triunfo contain cadmium (Méndez-Rodríguez and Álvarez-Castañeda 2016), and its assimilation and retention in the body is affected by the presence of zinc and iron (Schoendorfer and Davis 2012; Méndez-Rodríguez and Álvarez-Castañeda 2016).

The results regarding the accumulation of the various metals showed differences between sites as well as between rodent species. For instance, in San Juan de la Costa, cadmium content in C. rudinoris is inversely related to manganese content, while in C. spinatus cadmium varies inversely with nickel, and the amount of cadmium between these two species is inversely related. This indicates that, although both species may be sharing one or several types of seeds as food sources (review of cheek pouches, Gutierrez pers. obs.), the amount and composition of each seed type can influence the levels of each trace element that will eventually be bioaccumulated by each species. This is based on the fact that iron can either promote or prevent zinc uptake, depending on the proportion of these two elements (Lonnerdal 2000). In the rodents studied, a similar phenomenon may occur between copper and zinc, since in deposits with mining activity the relationship between these two elements is disrupted.

Mining operations may involve processes that change the chemical nature of elements, thus increasing or reducing their bioavailability (Ramírez et al. 2005). For instance, when the bioavailable fraction of copper increases, this element as well as cadmium displace zinc from metallothioneins; in turn, the zinc released induces the synthesis of methallothioneins (Bebianno and Langston 1991). A synergistic relationship between copper and zinc has been observed in tissues, that is, one element promotes the assimilation of the other; however, when the zinc:copper ratio is altered because one of these two elements accumulates at levels far above those of the other, then the relationship becomes antagonistic (Jonker et al. 2005; Nis et al. 2017).

In Santa Rosalia, copper extraction operations led us to expect that rodents accumulate copper in higher amounts relative to specimens of the same species in other locations with no copper mining. This was not observed (Table 1). In soil polluted by metals, the following situations may occur in plants: 1) the element is not bioavailable for uptake by the plant; 2 ) the plant fails to grow because of excess levels of the bioavailable trace element in soil; 3 ) the element is taken up from soil to the roots, but is not transported to other parts of the plant; or 4) the element is transported from the root to the seed or fruit (Allen 2002). According to the above, although in Santa Rosalia copper concentrations have been measured at levels up to $5,785 \mathrm{mg} \mathrm{kg}^{-1}$ in stream sediments and up to $33,192 \mathrm{mg} \mathrm{kg}^{-1}$ in mining waste, it is likely not bioavailable and, therefore, not recorded in rodents.

The bioavailability of a given element in soil is a critical factor for its uptake by an organism; this element may be affected by fluvial discharges or activities such as the application of materials that affect the $\mathrm{pH}$ or composition of soil, as is the case when mining takes place according to Ramírez et al. 2005. In San Juan de la Costa, Santa Rosalia, and El Triunfo, which are sites with deposits where mining operations have been conducted throughout history, rodents showed no significant increases in the trace elements analyzed in the liver, relative to specimens collected in areas with no mining activities (Table 1).

As regards species collected in the same locality, we expected to find no differences in metal concentrations between them. That is to say, we expected that all species of heteromids from a same deposit would reflect similar concentrations of metals in liver. However, it was found that C. spinatus accumulates significantly higher manganese and zinc levels than $C$. arenarius and D. simulans, which are the species coexisting with $C$. spinatus in some localities (Table 1). Since these species compete for the same food (Hunter et al. 1987; Gutierrez-Ramos and Álvarez-Castañeda 1999), any differences may be associated with the metabolism of each species, rather than with the degree of environmental pollution. It should be considered that manganese and zinc function as enzymatic cofactors (Aschner and Aschner 2005) and some species may require higher levels of these cofactors than others. For instance, it has been observed that more active or faster rodent species show a higher energy demand (Bozinovic and Gallardo 2005). The enzymes involved in energy production include pyruvate carboxylase, which uses manganese as a cofactor (Aschner and Aschner 2005). This element is also a cofactor of arginase, an enzyme associated with the concentration of urine (formed mainly by urea) that is part of a strategy for the optimization of metabolic water (MacMillen and Lee 1967; Brock et al. 1994). Urine concentration uses a large amount of energy (Frank 1988; Bozinovic and Gallardo 
2005). The various species likely have a differential capacity to concentrate urine and recover water from it, and this physiological process would be reflected in the concentration of chemical elements.

Lead concentrations recorded in the four species and in all deposits are below those considered as toxic for mammals (4.2 $\mu \mathrm{g} \cdot \mathrm{g}^{-1}$ dry weight; Ma 1996). The highest lead levels were found in heteromids living in San Juan de la Costa, where phosphorite is extracted; in Abreojos, where there is a non-exploited phosphorite deposit; and in El Triunfo, where gold and silver mining operations have been conducted but with no phosphorite deposits. This implies that the source of bioavailable lead may not be associated with phosphorite or its exploitation, but with another mineral or situation. Traditionally, the presence of lead is associated with the use of gasoline, which contained this metal until the 1990s (Soto-Jimenez and Flegal 2009). Lead is a conservative pollutant that persists in the environment; in addition, its presence in a mineral deposit is also attributed to its capacity to be transported by wind (Soto-Jimenez and Flegal 2009).

The results reported here showed the lack of consistency in the presence of trace elements in species living in a same deposit, as well as between sites. Our findings that the species living in a same deposit exhibit different trace metals levels support the conclusion that the concentration of trace elements in different species is influenced by different physical, chemical, and biological factors that differentially affect the ability to each species to take up the various trace metals. It is therefore relevant to further explore the synergistic and antagonistic processes related to zinc and copper, which together with metallothioneins and other detoxification mechanisms present in living organisms, may directly participate in the bioaccumulation of trace metals.

\section{Acknowledgments}

The authors wish to thank Mayra de La Paz from the Colección de Mastozoologia for her assistance throughout the study, as well as to Baudilio Acosta Vargas and Griselda Peña Armenta of the Laboratory of Atomic Absorption Spectrophotometry, all from the Centro de Investigaciones Biológicas del Noroeste, S. C. María Elena Sánchez-Salazar translated the manuscript into English.

\section{Cited literature}

AdRIANO, D. C. 2001. Trace elements in terrestrial environments: biogeochemistry, bioavailability, and risks of metals. Springer. New York, U.S.A.

AlleN, H. E. 2002. Bioavailability of metals in terrestrial ecosystems: Importance of partitioning for bioavailability to invertebrates, microbes and plants. Society of Environmental Toxicology and Chemistry.

Alshahri, F., and M. Alqahtani. 2015. Chemical fertilizers as a source of $238 \mathrm{U}, 40 \mathrm{~K}, 226 \mathrm{Ra}, 222 \mathrm{Rn}$, and trace metal pollutant of the environment in Saudi Arabia. Environmental Science and Pollution Research 22:8339-8348.
AsChner, J. L., AND M. AsChner. 2005. Nutritional aspects of manganese homeostasis. Molecular aspects of medicine 26:353-362.

Bebianno, M. J., AND W. J. Langston. 1991. Metallothionein induction in Mytilus edulis exposed to cadmium. Marine Biology 108:91-96.

BozinOVIC, F., AND P. Gallardo. 2006. The water economy of South American desert rodents: from integrative to molecular physiological ecology. Comparative Biochemistry and Physiology Part C: Toxicology and Pharmacology 142:163-172. Brock, A. A., S. A., Chapman, E. A. Ulman, And G. Wu. 1994. Dietary manganese deficiency decreases rat hepatic arginase activity. The Journal of nutrition 124:340-344.

Brown, J. H., AND G. A. LIBERMAN. 1973. Resource utilization and coexistence of seed-eating rodents in sand dune habits. Ecology 54:788-797.

Brown, J. H., O. J. Reichman, AND D. W. Davison. 1979. Granivory in desert ecosystems. Annual Review of Ecology and Systematics 10:788-797.

Dimitrov, H. A., V. I. Mitkovska, V. D. Tzekov, and T. G. Chassovnikarova. 2016. Bioaccumulation of Cadmium and Lead in Rodent Species from the Region of Lead-Zinc Smelting FactoryPlovdiv (South Bulgaria). Ecologia Balkanica 8:9-18.

Consejo de Recursos Minerales. 1999. Monografía geológicominera del estado de Baja California Sur. Secretaría de Comercio y Fomento Industrial. Coordinación General de Minería. Pachuca, México.

FLORIANCZYK, B. 2007. Metallothioneins and its role in metal regulation, binding of reactive oxygen species, apoptosis and cell differentiation. Journal of Pre-clinical and Clinical Research 1:16-18

Frank, C. L. 1988. The relationship of water content, seed selection, and the water requirements of a heteromyid rodent. Physiological Zoology 61:527-534.

Fritsch, C., R. P. Cosson, M. CEevidassier, F. Raoul, P. Giraudoux, N. CRINI, AND R. SCHEIFLER. 2010. Responses of wild small mammals to a pollution gradient: host factors influence metal and metallothionein levels. Environmental Pollution 158:827-840. Gutiérrez-Ramos, A., and S. T. Álvarez-Castañeda. 1999. Seed removal by heteromyid rodents in three habitats of tropical Mexico. Pp 211-222 in Ecology and management of forest, woodlands, and scrublands in the dryland region of the United States and Mexico: Perspectives for the 21st Century (Ffolliott, P. F., and A Ortega-Rubio, eds.). University of Arizona, Centro de Investigaciones Biológicas del Noroeste. La Paz, México.

HofFMeISTER, D. F. 1951. A taxonomic and evolutionary study of the piñon mouse, Peromyscus truei. Illinois Biological Monographs 21:1-104.

Hunter, B. A., M. S. Johnson, AND D. J. Thompson. 1987. Ecotoxicology of copper and cadmium in a contaminated grassland ecosystem. III. Small Mammals. Journal of Applied Ecology 24:601-614.

Iwal, T., M. Takahashi, K. Oda, Y. Terada, and K. T. Yoshida. 2012. DYNAmic ChANGes IN THE distribution of minerals in relation to phytic acid accumulation during rice seed development. Plant Physiology 160:2007-2014.

JANZEN, D. H. 1970. Herbivores and the number of three species in tropical forest. American Naturalist 104:501-528. 
Jonker, M. J., C. Svendsen, J. J. Bedaux, M. Bongers, and J. E. Kammenga. 2005. Significance testing of synergistic/antagonistic, dose level-dependent, or dose ratio-dependent effects in mixture dose-response analysis. Environmental Toxicology and Chemistry: An International Journal 24:2701-2713.

KIM, R. Y., J. K. Yoon, T. S. KIM, J. E. YANG, G. Owens, AND K. R. KIM. 2015. Bioavailability of heavy metals in soils: definitions and practical implementation-a critical review. Environmental Geochemistry and Health 37:1041-1061.

Lewis L. A., R. J. Poppenga, W. R. Davidson, J. R. Fischer, and K. A. MoRgAN. 2001. Lead toxicosis and trace element levels in wild birds and mammals at a firearms training facility. Archives of Environmental Contamination and Toxicology 41:208-214.

Linzey A. V., R. Timm, S. T. Álvarez-Castañeda, I. Castro-Arellano, And T. LACHER. 2008. Chaetodipus spinatus. In, IUCN 2013. IUCN. Red List of Threatened Species. Version 2015.1. http://www. iucnredlist.org/details/4338/0.

LONNERDAL, B. 2000. Dietary factors influencing zinc absorption. The Journal of Nutrition 130:1378S-1383S.

MA, W. 1996. Lead in mammals. Pp. 281-296 in Environmental contaminants in wildlife: interpreting tissue concentrations (Beyer, W. N., G. H. Heinz, and A. W. Redmond-Norwood, eds). Second edition. Lewis. Boca Raton, U.S.A.

MacMillen, R. E., And A. K. Lee. 1967. Australian desert mice: independence of exogenous water. Science 158:383-385.

MACMILLERN, E., AND D. S. HindS. 1983. Water regulatory efficiency in heteromyid rodents: a model and its application. Ecology 64:152-164.

MARES, M. A. 1993. Heteromyids and their ecological counterparts: A pandesertic view of rodent ecology and evolution. Pp. 652-701 in Biology of the Heteromyidae (Genoways, H. H., and J. H Brown, eds.). The American Society of Mammalogists, Special Publication. Lawrence, U.S.A.

Marques, C. C., A. Sánchez-Chardi, S. I. Gabriel, J. Nadal, A. M. ViegasCRespo, and M. Da Luz Mathias. 2007. How does the greater white-toothed shrew, Crocidura russula, responds to longterm heavy metal contamination?-A case study. Science of the Total Environment 376:128-133.

Milton, A., J. A., Cooke, And M. S. Johnson. 2003. Accumulation of lead, zinc, and cadmium in a wild population of Clethrionomys glareolus from an abandoned lead mine. Archives of Environmental Contamination and Toxicology 44:405-411.

Mikolić, A., Schönwald, N., and M. Piasek. 2016. Cadmium, iron and zinc interaction and hematological parameters in rat dams and their offspring. Journal of Trace Elements in Medicine and Biology 38:108-116.

Méndez-Rodríguez, L. C., and S. T. Álvarez-Castañeda. 2016. Assessment of trace metals in soil, vegetation and rodents in relation to metal mining activities in an arid environment. Bulletin of Environmental Contamination and Toxicology 97:44-49.

Milton, A., Cooke, J. A., And M. S, Johnson. 2003. Accumulation of lead, zinc, and cadmium in a wild population of Clethrionomys glareolus from an abandoned lead mine. Archives of Environmental Contamination and Toxicology 44:405-411.

Patton, J. L., And S. T. Álvarez Castañeda. 1999. Family Heteromyidae. Pp. 351-443 in Mamíferos del Noroeste Mexicano (Álvarez Castañeda, S. T., y J. L. Patton, eds.). Centro de Investigaciones
Biológicas del Noroeste, S. C. La Paz, México.

Nys, C., T. Van Regenmortel, C. R. Janssen, R. Blust, E. Smolders, and K. A. Schamphelaere. 2017. Comparison of chronic mixture toxicity of nickel-zinc-copper and nickel-zinc-coppercadmium mixtures between Ceriodaphnia dubia and Pseudokirchneriella subcapitata. Environmental Toxicology and Chemistry 36:1056-1066.

PetkovšEk, S. A. S., KopušAr, N., AND B. Kryštufek. 2014. Small mammals as biomonitors of metal pollution: a case study in Slovenia. Environmental Monitoring and Assessment 186:4261-4274.

PAIS, I., AND J. B. JONES, JR. 1997. The handbook of trace elements. CRC Press. Boca Raton, U.S.A.

Ramirez, M., S. Massolo, R. Frache, and J. A. Correa. 2005. Metal speciation and environmental impact on sandy beaches due to El Salvador copper mine, Chile. Marine Pollution Bulletin, 50: 62-72.

Servicio Geológico Mexicano. 2017. Panorama minero del Estado de Baja California Sur. México. Secretaria de Economía, Servicio Geológico Mexicano, Coordinación General de Minería and Secretaría de Gobernación. Ciudad de México, México.

Schmidt-Nielsen, K. 1964. Desert animals. Physiological problems of heat and water. Desert animals. Physiological problems of heat and water. Oxford University Press. London, U.K.

Schmidt-Nielsen, K. 1972. How animals work. Cambridge University Press, London, U.K.

Schoendorfer, N., AND P. S. DAvies. 2012. Micronutrient interrelationships: Synergism and antagonism, Pp 159-177 in Micronutrients (Betancourt, A. I., and H. F. Gaitan, eds). First edition. Nova Science Publishers, Inc. New York, U.S.A.

Shumilin, E. N., Rodríguez-Figueroa, G., Bermea, O. M., Baturina, E. L., Hernández, E., and G. D. R. Meza. 2000. Anomalous trace element composition of coastal sediments near the copper mining district of Santa Rosalía, Peninsula of Baja California, Mexico. Bulletin of Environmental Contamination and Toxicology 65:261-268.

Soto-Jiménez, M. F., and A. R. Flegal. 2009. Origin of lead in the Gulf of California Ecoregion using stable isotope analysis. Journal of Geochemical Exploration, 101:209-217.

TALMAGE S. S., AND B. T.WALTON. 1991. Small mammals as monitors of environmental contaminants. Pp. 47-145 in Reviews of Environmental Contamination and Toxicology. Springer. New York, U. S. A.

TAYLOR, S. R. 1964. Abundance of chemical elements in the continental crust: a new table. Geochimica et Cosmochimica Acta 28:1273-1285.

TorRes K. C., AND M. L. Johnson. 2001. Bioaccumulation of metals in plants, arthropods, and mice at a seasonal wetland. Environmental Toxicology and Chemistry 20:2617-2626.

VAN Loon, J. C. 1985. Selected methods of trace metal analysis: biological and environmental samples. John Wiley and Sons. U.S.A.

VAŠÁK, M., AND G. MELONI. 2011. Chemistry and biology of mammalian metallothioneins. JBIC Journal of Biological Inorganic Chemistry 16:1067-1078.

$Z_{A R}$, J. H. 2010. Biotatistical analysis. 5th editon. Prentice Hall. Upper Saddle River, U.S.A. 
Associated editor: Juan Pablo Gallo

Submitted: June 24, 2019; Reviewed: September 10, 2019;

Accepted:September 15, 2019; Published on line:September 24, 2019. 